\title{
Sifat Fisik, Organoleptik dan Aktivitas Antioksidan Sosis Ayam dengan Penambahan Ekstrak Daun Sirsak (Annona muricata 1. )
}

\section{Physical, Organoleptic and Antioxidant Quality of Chicken Sausage with Soursop Leaf Extract (Annona muricata l.) Addition}

\section{Arif Ismanto* dan Sitiani Subaihah}

Jurusan Peternakan, Fakultas Pertanian, Universitas Mulawarman, Samarinda 75123, Indonesia

\begin{tabular}{|c|c|}
\hline & Abstract \\
\hline $\begin{array}{l}\text { Article history } \\
\text { Received: Jan 11, 2020; } \\
\text { Accepted: Mar 7, } 2020 \\
\text { * Corresponding author: } \\
\text { E-mail: } \\
\text { arifismanto9@gmail.com } \\
\text { DOI: https://doi.org/10.46549/ } \\
\text { jipvet.v10i1.84 }\end{array}$ & $\begin{array}{l}\text { This study aims to determine the effect of adding soursop leaf extract } \\
\text { (SLE) at level } 0 \text { (control), 2, } 4 \text {, and } 6 \% \text { (the weight of SLE /the weight of the } \\
\text { dough) on the physical, organoleptic and antioxidant qualities of chicken } \\
\text { sausages. A Completely Randomized Design (CRD) was used in this study. } \\
\text { Data analysis was performed using analysis of variance (ANOVA) and further } \\
\text { tested using the Least Significant Difference Test (LSD). The results showed } \\
\text { that differences in SLE levels did not significantly affect the physical quality of } \\
\text { chicken sausages, but did change the color, aroma, texture, and taste. The color, } \\
\text { smell, texture, and taste of chicken sausage with the addition of } 6 \% \text { SLE showed } \\
\text { results that appeared to be greener, had a stronger soursop aroma, more elastic, } \\
\text { and tasted more bitter than the other treatments (P <0.05). The lowest } \\
\text { antioxidant activity was shown by SLE 0\% in both the dough (39.78\%) and } \\
\text { cooked sausage (17.10\%). The highest antioxidant activity was SLE 6\%, with } \\
\text { antioxidant activity of } 57.63 \% \text { in the dough and } 37.43 \% \text { in cooked sausages. } \\
\text { The addition of chicken sausage does not affect physical quality but has a } \\
\text { significant impact on the soursop leaf extract test on organoleptic color, aroma, } \\
\text { texture, and taste. The best organoleptic quality is demonstrated at } 4 \% \text { SLE. } \\
\text { The addition of soursop leaf extract level is accompanied by increased levels of } \\
\text { antioxidants both in the dough and in cooked sausage. }\end{array}$ \\
\hline & $\begin{array}{l}\text { Keywords: Antioxidants; Chicken sausage; Organoleptic; Physical quality; } \\
\text { Soursop leaf extract }\end{array}$ \\
\hline
\end{tabular}

\section{PENDAHULUAN}

Daging ayam broiler memungkinkan untuk diolah menjadi produk-produk pangan seperti sosis, kornet, nugget, dan lain sebagainya. Sosis adalah bahan pangan yang berasal dari potongan daging yang digiling dan diberi bumbu dan dapat langsung disiapkan dan segera dimasak untuk dikonsumsi (Rosida et al., 2015). Sosis merupakan produk olahan yang telah dikenal dan banyak diminati oleh masyarakat karena bersifat cepat saji, memiliki rasa yang lezat, aroma yang nikmat dan pembuatannya yang mudah. Konsumsi sosis oleh masyarakat Indonesia tumbuh rata-rata 4,46\% per tahun (Anggraeni et al., 2014).

Sosis difortifikasi untuk meningkatkan kualitas atau membuat sosis menjadi produk yang memiliki nilai lebih. Upaya-upaya fortifikasi yang telah dilakukan pada produk sosis yaitu dengan menambahkan bahan labu merah pada sosis untuk melihat fisika kimia, antioksidan serta sebagai pewarna alami pada sosis (Khotimah et al., 2013). Fortifikasi lainnya yaitu pembuatan sosis ayam dengan gel porang sebagai bahan pengikat terhadap karakteristik sosis (Prastini et al., 2015).

Tanaman sirsak berasal dari bahasa Belanda yaitu zuurzak yang berarti kantong asam dengan nama ilmiah Annona muricata $\mathrm{L}$. Tanaman sirsak tersebar luas di daerah tropis dan subtropis. Daun sirsak memiliki kandungan antioksidan yang berfungsi sebagai antikanker, antibakteri, menurunkan kolesterol dalam darah, serta mampu menurunkan kadar asam 
urat (Cresna, 2014). Penelitian sebelumnya oleh Fauziah et al. (2012) melaporkan bahwa ekstrak sirsak merupakan salah satu dari beberapa ekstrak tanaman lain dengan kandungan antioksidan yang mampu menurunkan kandungan radikal bebas pada daging sapi yang diradiasi dengan sinar gamma.

Penelitian ini dilakukan untuk mengetahui karakteristik sosis ayam yang diberi penambahan ekstrak daun sirsak ditinjau dari kualitas fisik, organoleptik dan kadar antioksidan.

\section{MATERI DAN METODE}

\section{ALAT DAN BAHAN}

Alat yang digunakan untuk pembuatan ekstrak daun sirsak yaitu blender dan kertas saring. Pembuatan sosis ayam (penggiling daging, sarung tangan, mixer, selongsong sosis, baskom, panci, dan kompor). Alat yang digunakan untuk pengujian kualitas fisik sosis ayam yaitu $\mathrm{pH}$ meter dan beaker glass. Pengujian daya ikat air (timbangan, kertas saring, lempengan kaca, plastik transparan, spidol permanen dan beban $35 \mathrm{~kg}$ ). Alat yang digunakan untuk pengujian susut masak yaitu tisue dan timbangan digital. Alat yang digunakan untuk pengujian organoleptik yaitu kuisioner. Pengujian antioksidan sosis ayam (waterbath, spektrofotometer, labu ukur, dan tabung reaksi).

Bahan utama yang digunakan untuk penelitian yaitu daun sirsak, daging ayam dan DPPH. Bahan tambahan yang digunakan yaitu etanol 95\%, garam, bawang putih, merica, ketumbar, gula, tepung tapioka, aquades, susu skim dan minyak nabati.

\section{RANCANGAN PERCOBAAN}

Rancangan percobaan yang dilakukan dalam penelitian ini adalah Rancangan Acak Lengkap (RAL). Penelitian ini menggunakan empat perlakuan yaitu level ekstrak daun sirsak 0, 2, 4 dan 6\% dengan empat ulangan.

\section{PROSEDUR PENELITIAN}

Prosedur penelitian terdiri dari pembuatan ekstrak daun sirsak, penyiapan sosis ayam, pengujian kualitas fisik dan organoleptik sosis ayam dan pengujian antioksidan.

\section{PEMBUATAN EKSTRAK DAUN SIRSAK}

Pembuatan ekstrak daun sirsak dilakukan sesuai metode modifikasi Diantoro et al. (2015) dengan menggunakan daun sirsak pada baris ke 3-5 dari pucuk daun muda, selanjutnya daun dicuci bersih. Daun sirsak ditimbang sebanyak 100 gram, kemudian daun dihaluskan dengan blender dengan penambahan $200 \mathrm{ml}$ air.

\section{PENYIAPAN SOSIS AYAM}

Pembuatan sosis dilakukan dengan menggunakan daging ayam bagian pectoralis superficialis dan pectoralis profundus. Penggilingan daging ayam menggunakan meat grind, kemudian hasil gilingan dicampurkan dengan tepung tapioka beserta bumbubumbunya. Ekstrak daun sirsak juga ditambahkan dengan dosis $0 \%, 2 \%, 4 \%$, dan 6\%. Sosis kontrol (0\%) disiapkan tanpa penambahan ekstrak daun sirsak. Setiap bahan dicampurkan dengan menggunakan mixer selama 3 menit. Adonan dimasukkan ke dalam selongsong sosis (diameter $30 \mathrm{~mm}$ ) menggunakan stuffer. Sosis dikukus kemudian dilakukan pengujian kualitas fisik, organoleptik dan antioksidan.

\section{Pengujian KUAlitas Fisik SOSIS AYAm}

Pengujian kualitas fisik sosis ayam meliputi $\mathrm{pH}$, susut masak, dan daya ikat air.

1. Nilai $\mathrm{pH}$

Penentuan nilai pH pada penelitian ini dilakukan sesuai metode Irawati et al. (2015) dengan menggunakan sosis seberat $5 \mathrm{~g}$ yang dimasukkan ke dalam wadah gelas beaker, kemudian sosis dicampur dengan aquades sebanyak $10 \mathrm{~mL}$ lalu dihomogenkan selama 1 menit. Pengukuran $\mathrm{pH}$ dilakukan dengan menggunakan $\mathrm{pH}$ meter.

\section{Susut masak}

Susut masak pada penelitian ini dilakukan sesuai metode Suradi (2006) dengan memasukkan sosis kedalam air yang sedang direbus selama 30 menit. Mengangkat sampel tersebut kemudian dilap menggunakan tisu, kemudian ditimbang menggunakan timbangan digital sehingga diperoleh nilai susut masak. Susut masak dihitung dengan menggunakan rumus sebagai berikut: 


$$
\text { Susut masak }(\%)=\frac{\text { Berat sampel awal - berat sampel akhir }}{\text { Berat sampel awal }} \times 100 \%
$$

3. Daya ikat air

Daya ikat air pada penelitian ini dilakukan sesuai metode Laksmi et al. (2012) dengan menggunakan sosis seberat $0,3 \mathrm{~g}$ yang diletakkan diatas kertas saring, kemudian sampel di letakkan diantara dua lempengan kaca dan diberi beban seberat $35 \mathrm{~kg}$ selama 5 menit. Setelah 5 menit beban seberat $35 \mathrm{~kg}$ dan lempengan kaca disingkirkan, maka akan terlihat sampel daging menjadi rata dan terdapat luas daerah basah disekitar daging.
Memberikan tanda pada daerah yang basah dan daerah daging dengan menggunakan plastik transparan kemudian diukur luasnya dengan menggunakan kertas millimeter (mm) blok. Kadar air total dilakukan dengan cara mengoven sosis seberat $5 \mathrm{~g}$ menggunakan cawan selama 24 jam dengan suhu $105{ }^{\circ} \mathrm{C}$. Dinginkan cawan yang berisi sampel ke dalam desikator kemudian ditimbang. Daya ikat air dapat diukur dengan menggunakan rumus sebagai berikut:

$$
\begin{gathered}
\text { Kadar air }(\%)=\frac{\text { Berat sampel awal - berat sampel akhir }}{\text { Berat sampel awal }} \times 100 \% \\
\text { Berat } H 2 O(g)=\frac{\text { Area basah }(\mathrm{cm} 2)}{0,0948}-8 \\
\text { Kadar air bebas }(g)=\frac{\text { Berat } H 2 O}{\text { Berat sampel }} \times 100 \%
\end{gathered}
$$$$
\text { Daya Ikat Air = Kadar air total (\%) - Kadar air bebas (\%) }
$$

\section{UJI ORGANOLEPTIK}

Uji organoleptik pada penelitian ini dilakukan sesuai metode Irawati et al. (2015) dengan cara panelis merespon tekstur, aroma, warna dan daya terima suatu produk. Uji organoleptik dilakukan dengan menggunakan panelis sebanyak 25 orang. Penilaian panelis menggunakan kuisioner yang telah disediakan. Uji hedonik warna, aroma, tekstur dan rasa dinilai dengan skor 1 (sangat tidak suka) sampai

\begin{tabular}{|c|c|c|c|c|}
\hline Skor & Warna & Aroma & Tekstur & Rasa \\
\hline 1 & Putih & Beraroma daging & Kasar & Tidak pahit \\
\hline 2 & Putih kehijauan & $\begin{array}{l}\text { Sedikit beraroma } \\
\text { daging }\end{array}$ & Agak kasar & Sedikit pahit \\
\hline 3 & Hijau muda & $\begin{array}{l}\text { Agak beraroma } \\
\text { daun sirsak }\end{array}$ & Kenyal & Agak pahit \\
\hline 4 & Hijau & $\begin{array}{l}\text { Beraroma daun } \\
\text { sirsak }\end{array}$ & Tidak kenyal & Pahit \\
\hline 5 & Sangat hijau & $\begin{array}{l}\text { Sangat beraroma } \\
\text { daun sirsak }\end{array}$ & Halus & Sangat pahit \\
\hline
\end{tabular}
5 (sangat suka), kemudian untuk uji mutu hedonik dapat dilihat pada Tabel 1.

Tabel 1. Uji mutu hedonik

\section{UJI ANTIOKSIDAN}

Uji kadar antioksidan dilakukan menurut metode Farhan et al. (2012) menggunakan spektrofotometri dengan metode DPPH (2,2diphenyl-1-picrylhydrazy). Sampel seberat $10 \mathrm{~g}$ dihaluskan kemudian dimaserasi dengan menggunakan etanol $95 \%$ dengan perbandingan $1: 3$ dan direndam selama 24 jam dengan keadaan tertutup. Hasil rendaman kemudian disaring dan diuapkan menggunakan 
waterbath sehingga diperoleh ekstrak kental. Sebanyak $1 \mathrm{~mL}$ ekstrak yang telah diencerkan dengan etanol ditambahkan ke $1 \mathrm{~mL} \mathrm{DPPH}$ pada saat yang sama. Campuran reaksi dicampur dengan baik lalu diinkubasi dalam keadaan gelap selama 30 menit. Absorbansi diukur pada panjang gelombang $517 \mathrm{~nm}$ menggunakan alat spektrofotometer UV. Kemampuan ekstrak DPPH dihitung dengan menggunakan rumus sebagai berikut:

$$
\text { Antioksidan }(\%)=\frac{\text { Absorbansi kontrol }- \text { Absorbansi sampel }}{\text { Absorbansi kontrol }} \times 100
$$

\section{ANALISIS DATA}

Analisis data hasil uji organoleptik sosis dengan penambahan ekstrak daun sirsak dengan level yang berbeda diuji menggunakan Kruskal Wallis. Uji kualitas fisik dan antioksidan diuji menggunakan ANOVA, jika berbeda nyata diuji lanjut menggunakan BNT (Beda Nyata Terkecil) dengan tingkat kepercayaan $5 \%$.

\section{HASIL DAN PEMBAHASAN}

\section{UJI KUALITAS FISIK SOSIS}

Kualitas fisik sosis ayam dengan penambahan ekstrak daun sirsak yang diuji dalam penelitian ini yaitu nilai $\mathrm{pH}$, susut masak dan daya ikat air. Nilai rataan dan standar deviasi kualitas fisik dapat dilihat pada Tabel 2.

Tabel 2. Nilai pH, susut masak dan daya ikat air sosis ayam

$\begin{array}{cccc}\begin{array}{r}\text { Level Ekstrak Daun Sirsak } \\ \text { (EDS) }(\%)\end{array} & \begin{array}{c}\text { Parameter } \\ \text { Nilai pH }\end{array} & \text { Susut masak }(\%) & \text { Daya Ikat Air }(\%) \\ 0 & 5,6 \pm 0,00 & 3,65 \pm 1,94 & 60,27 \pm 2,31 \\ 2 & 5,6 \pm 0,00 & 2,80 \pm 0,99 & 58,79 \pm 0,64 \\ 4 & 5,6 \pm 0,00 & 5,07 \pm 2,13 & 58,98 \pm 1,72 \\ 6 & 5,6 \pm 0,00 & 2,78 \pm 0,62 & 58,27 \pm 0,85\end{array}$

Nilai $\mathrm{pH}$ sosis ayam broiler yang diberi penambahan ekstrak daun sirsak dengan level yang berbeda dapat dilihat pada Tabel 2. Hasil analisis perhitungan statistik pada setiap perlakuan menunjukan bahwa penambahan ekstrak daun sirsak pada level yang berbeda tidak berpengaruh nyata $(\mathrm{P}>0,05)$ terhadap nilai $\mathrm{pH}$ sosis ayam. Nilai $\mathrm{pH}$ yang diperoleh pada tiap perlakuan memiliki nilai yang sama yaitu 5,6. Hasil $\mathrm{pH}$ pada penelitian ini lebih rendah jika dibandingkan dengan $\mathrm{pH}$ daging ayam broiler yang masih segar yaitu 6.0, hal ini kemungkinan disebabkan oleh suhu tinggi pada saat pengukusan sosis. Hal ini sesuai dengan pendapat Suradi (2006) yang menyatakan bahwa suhu yang tinggi dapat mempercepat penurunan $\mathrm{pH}$ yang disebabkan oleh peningkatan denaturasi protein. Irianto et al. (1994) yang disitasi oleh Yusuf et al. (2016) menyatakan bahwa sosis ayam yang beredar di pasaran memiliki nilai $\mathrm{pH}$ yang berkisar antara 5,12-7,20 hal ini menunjukkan bahwa hasil nilai $\mathrm{pH}$ pada penelitian ini masih pada kondisi yang normal.
Susut masak sosis ayam broiler yang diberi penambahan ekstrak daun sirsak dengan level yang berbeda dapat dilihat pada Tabel 2. Hasil analisis statistik yang telah dilakukan pada susut masak sosis yang telah diberi penambahan ekstrak daun sirsak dengan level yang berbeda menunjukkan tidak berpengaruh nyata $(\mathrm{P}>0,05)$. Kandungan protein pada masing-masing perlakuan relatif sama karena jumlah daging yang digunakan beratnya sama, hal ini menyebabkan susut masak tidak berpengaruh nyata. Bouton et al. (1978) menyatakan pada umumnya susut masak bervariasi antara $1,5 \%$ sampai $54,5 \%$. Daging dengan susut masak lebih rendah mempunyai kualitas yang lebih baik dari pada daging dengan susut masak yang tinggi, karena dengan susut masak yang lebih rendah menunjukkan bahwa selama pemasakan potensi kehilangan air dan jumlah zat gizi lainnya lebih sedikit. Susut masak dipengaruhi oleh protein, semakin banyak protein pada suatu produk, maka semakin kecil tingkat susut masak. Pendapat ini sesuai dengan Irawati et al. (2015) yang menyatakan bahwa protein mempengaruhi 
penurunan dan kenaikan susut masak sebab protein dapat mengikat air. Protein akan menahan air sehingga air yang keluar semakin sedikit sehingga susut masak berkurang.

Daya ikat air (DIA) sosis ayam broiler yang diberi penambahan ekstrak daun sirsak dengan level yang berbeda dapat dilihat pada Tabel 2. Hasil analisis statistik yang telah dilakukan pada sosis yang telah diberi penambahan ekstrak daun sirsak dengan level yang berbeda menunjukkan bahwa penambahan ekstrak daun sirsak level $0,2,4$ dan $6 \%$ tidak berpengaruh nyata $(\mathrm{P}>0,05)$ terhadap daya ikat air sosis ayam. Hasil pengamatan DIA memiliki nilai 58,27\% sampai $60,27 \%$.

Hasil perhitungan daya ikat air (DIA) yang tidak berpengaruh nyata berkaitan dengan nilai pH. Hal ini sesuai dengan pendapat Sofiana (2012) yang menyatakan bahwa daya mengikat air dipengaruhi oleh $\mathrm{pH}$. Nilai $\mathrm{pH}$ yang ideal agar DIA tinggi yaitu pada kisaran antara 5,1 sampai 6,1 . Hasil penelitian diperoleh rataan nilai $\mathrm{pH}$ dengan rata-rata yaitu 5,6 hal ini menunjukkan bahwa nilai $\mathrm{pH}$ pada sosis ayam pada perlakuan masih dalam kategori yang baik. DIA dan $\mathrm{pH}$ daging juga berkaitan dengan susut masak (cooking loss). Cooking loss rendah maka dapat memperoleh hasil DIA yang tinggi. Nilai DIA sosis sangat dipengaruhi oleh penghancuran daging selama pengolahan. Struktur daging yang rusak selama pengolahan mengakibatkan berkurangnya DIA. Sofiana (2012) berpendapat bahwa adanya jaringan ikat (kolagen) dapat meningkatkan daya ikat air selama pencampuran pada proses pembuatan sosis.

\section{UJI ORGANOLEPTIK SOSIS}

Uji organoleptik sosis ayam dengan penambahan ekstrak daun sirsak yang diamati yaitu hedonik dan mutu hedonik warna, aroma, tekstur dan rasa.

WARNA SOSIS DENGAN PENAMBAHAN EKSTRAK DAUN SIRSAK

Hasil pengujian hedonik dan mutu hedonik warna sosis dengan penambahan ekstrak daun sirsak dapat dilihat pada Gambar 3.

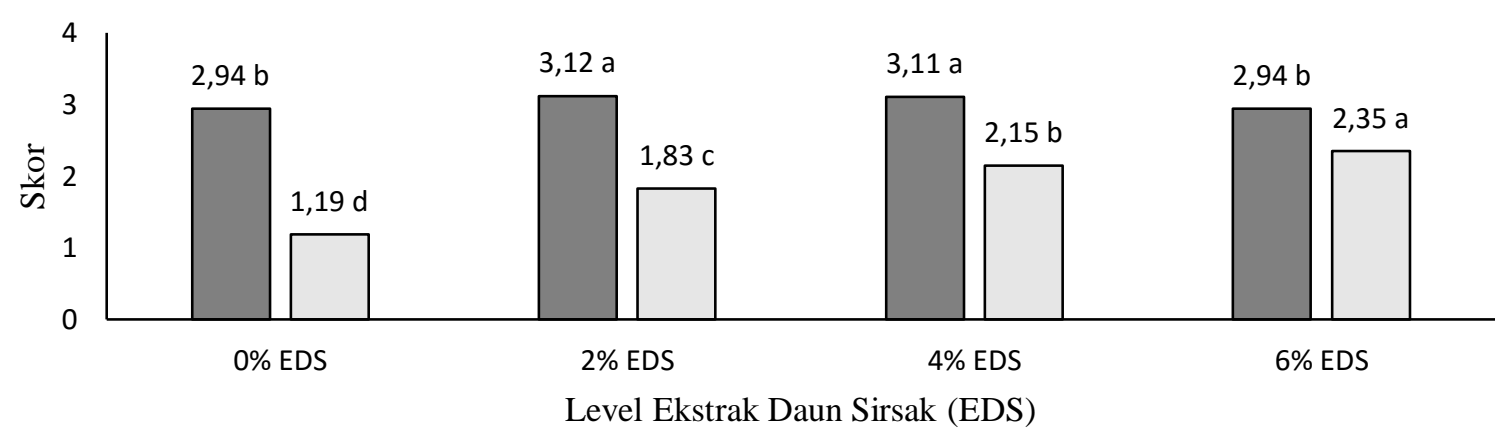

$\square$ Hedonik warna 1-5 (sangat tidak suka - sangat suka)

$\square$ Mutu hedonik warna 1-5 (putih - sangat hijau)

\section{Gambar 1. Uji skala hedonik dan mutu hedonik warna}

Hasil analisis statistik yang telah dilakukan pada uji hedonik dan mutu hedonik warna sosis yang diberi penambahan ekstrak daun sirsak dengan level yang berbeda menunjukkan hasil yang berpengaruh nyata $(\mathrm{P}<0,05)$ terhadap warna sosis ayam. Warna sosis dengan penambahan ekstrak daun sirsak sebanyak $2 \%$ dan $4 \%$ lebih disukai oleh panelis dibandingkan sosis dengan penambahan ekstrak daun sirsak $0 \%$ dan $6 \%$.

Warna sosis dengan penambahan ekstrak daun sirsak $2 \%$ dan $4 \%$ memperoleh nilai 3 (agak suka) sampai 4 (suka). Intensitas warna hijau yang dinilai oleh panelis menunjukkan bahwa penambahan ekstrak daun sirsak sebanyak $6 \%$ menghasilkan warna yang lebih hijau dibanding dengan sosis kontrol. Warna hijau yang dihasilkan masih dalam kisaran 2 (putih kehijauan) sampai 3 (hijau muda). Chintya et al. (2017) menyatakan bahwa tanin pada daun sirsak dapat digunakan sebagai pewarna alami yang ramah lingkungan. Semakin tinggi kadar tanin, maka akan semakin gelap pula warna yang didapat. Lebih lanjut 
ditambahkan oleh Aulia (2017) bahwa selain tanin daun sirsak mengandung klorofil atau lebih dikenal juga dengan sebutan zat hijau daun sehingga menghasilkan warna hijau pekat yang dapat digunakan sebagai pewarna alami. Semakin banyak ekstrak daun sirsak yang diberikan, maka akan menghasilkan warna yang lebih hijau pula.

Warna pada suatu produk pangan memiliki peran penting sebagai daya tarik pertama pada konsumen sebagai penentu diterima atau ditolaknya suatu produk. Warna menjadi atribut yang sangat menentukan dalam pengambilan keputusan pembelian baik pada bahan baku berupa karkas ayam maupun produk olahannya (Ismanto et al., 2018).

\section{AROMA SOSIS DENGAN PENAMBAHAN EKSTRAK DAUN SIRSAK}

Hasil pengujian hedonik dan mutu hedonik aroma sosis dengan penambahan ekstrak daun sirsak dapat dilihat pada Gambar 2.

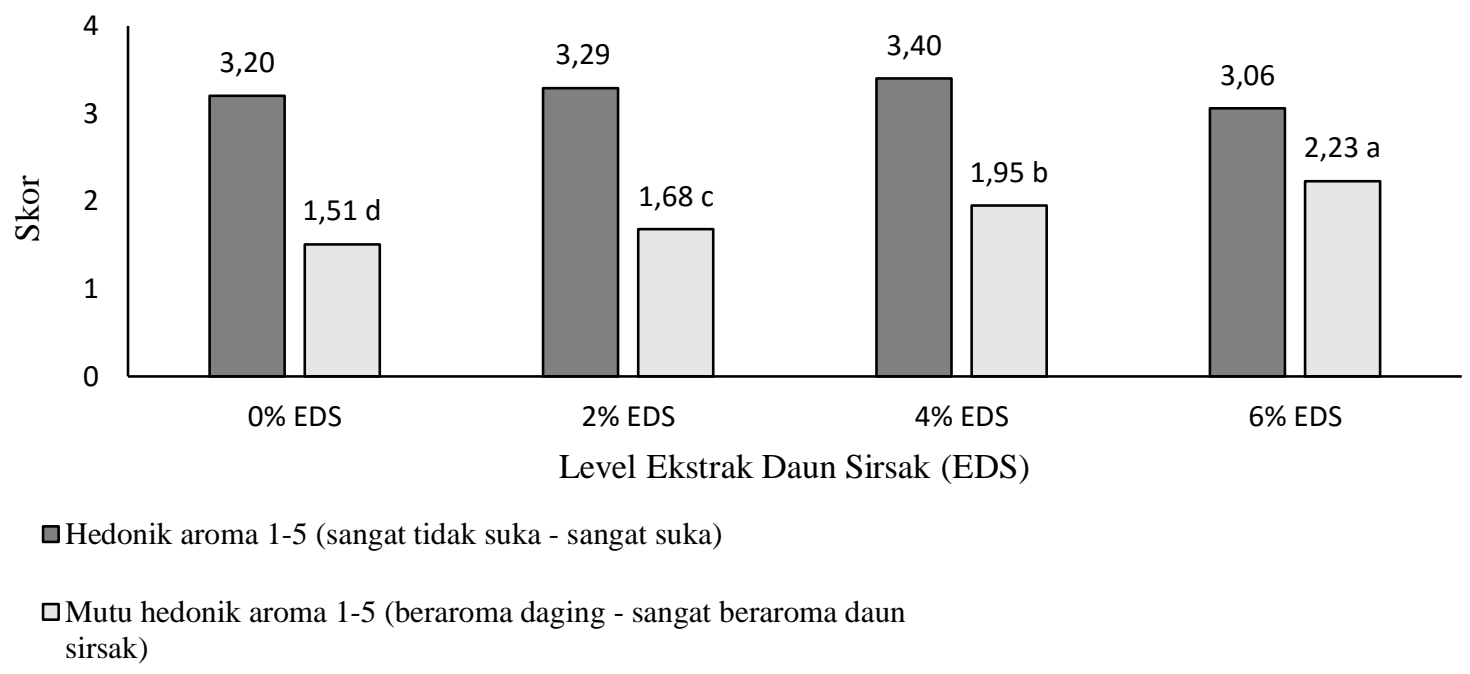

\section{Gambar 2. Uji skala hedonik dan mutu hedonik aroma}

Hasil analisis statistik yang telah dilakukan pada uji hedonik aroma sosis yang telah diberi penambahan ekstrak daun sirsak dengan level yang berbeda menunjukkan hasil tidak berpengaruh nyata $(\mathrm{P}>0,05)$ terhadap tingkat kesukaan sosis ayam, sedangkan pada uji mutu hedonik menunjukkan hasil yang berpengaruh nyata $(\mathrm{P}<0,05)$ terhadap aroma sosis ayam. Aroma sosis dengan penambahan ekstrak daun sirsak sebanyak $4 \%$ lebih disukai oleh panelis dibandingkan sosis dengan penambahan ekstrak daun sirsak 0\%, 2\% dan 6\%. Warna sosis dengan penambahan ekstrak daun sirsak 4\% memperoleh nilai 3 (agak suka) sampai 4 (suka). Aroma daun sirsak yang dinilai oleh panelis menunjukkan bahwa penambahan ekstrak daun sirsak sebanyak 6\% menunjukan nilai 2 (sedikit beraroma daging) sampai 3 (agak beraroma daun sirsak). Penambahan ekstrak daun sirsak berpengaruh pada aroma sosis. Aulia (2017) menyatakan bahwa aroma langu disebabkan oleh minyak atsiri dan senyawa acetogenin yang terdapat pada daun sirsak yang memberikan karakteristik khusus pada produk. Aroma merupakan faktor penting dalam industri pangan sebab aroma dapat dengan cepat memberikan hasil penilaian diterimanya atau ditolaknya suatu produk.

\section{TEKSTUR SOSIS DENGAN PENAMBAHAN EKSTRAK DAUN SIRSAK}

Hasil pengujian hedonik dan mutu hedonik tekstur sosis dengan penambahan ekstrak daun sirsak dapat dilihat pada Gambar 3.

\section{RASA SOSIS DENGAN PENAMBAHAN EKSTRAK DAUN SIRSAK}

Hasil pengujian hedonik dan mutu hedonik rasa sosis dengan penambahan ekstrak daun sirsak dapat dilihat pada Gambar 4. 


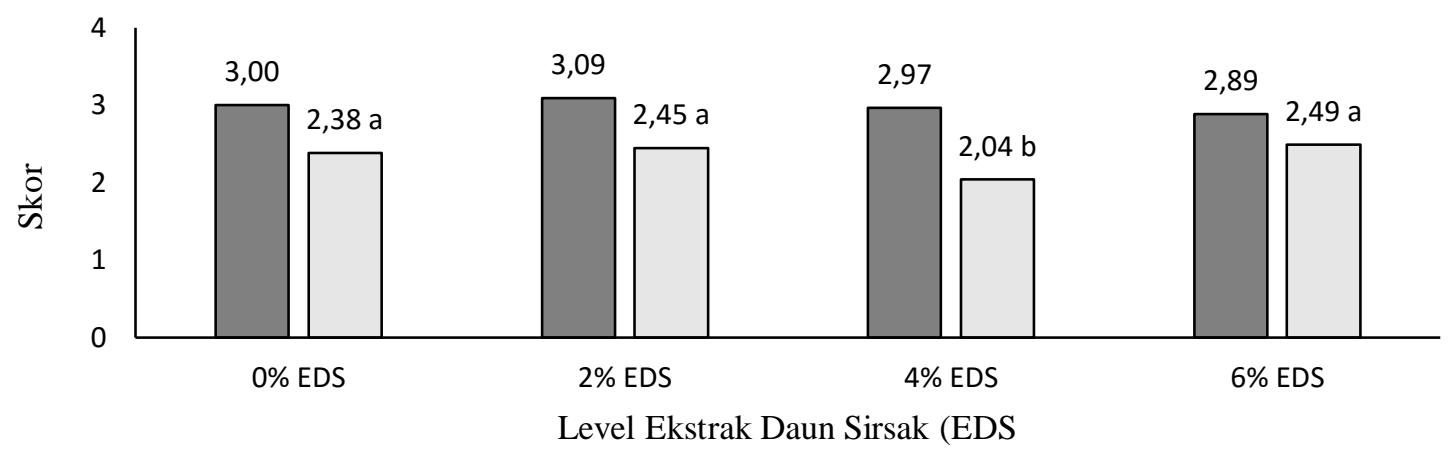

$\square$ Hedonik tekstur 1-5 (sangat tidak suka - sangat suka)

口Mutu hedonik tekstur 1-5 (kasar - halus)

Gambar 3. Uji skala hedonik dan mutu hedonik tekstur

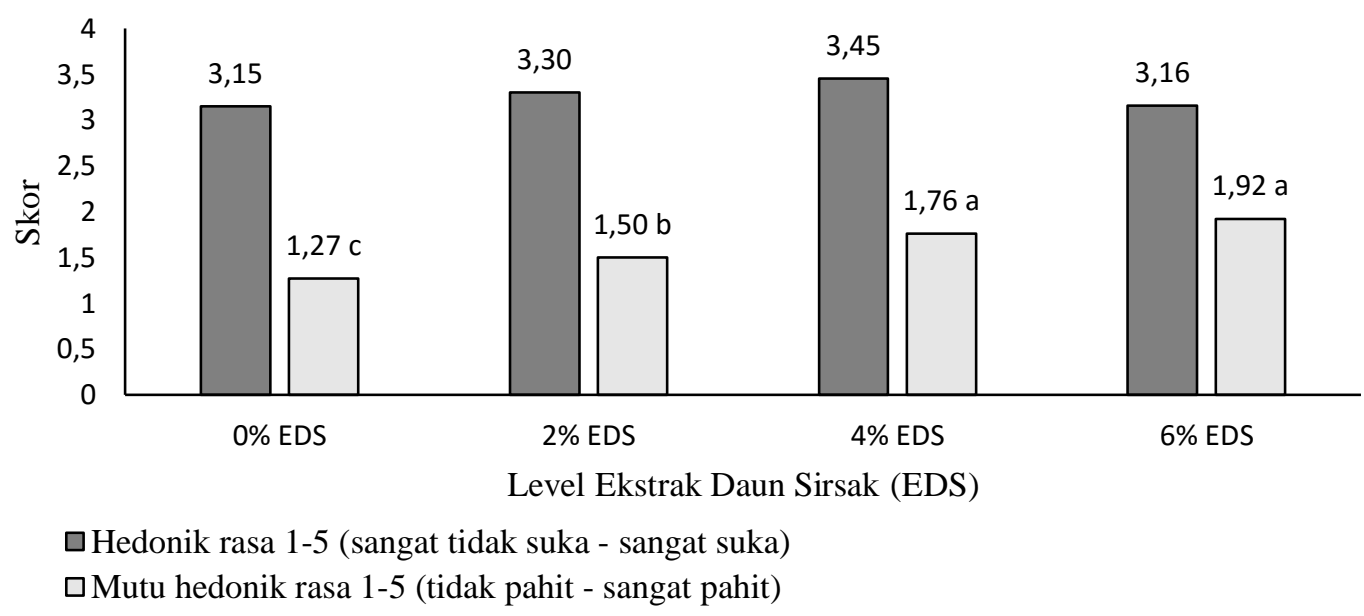

\section{Gambar 4. Uji skala hedonik dan mutu hedonik rasa}

Hasil analisis statistik yang telah dilakukan pada uji hedonik rasa yang telah diberi penambahan ekstrak daun sirsak dengan level yang berbeda menunjukkan hasil tidak berpengaruh nyata $(\mathrm{P}>0,05)$ terhadap tingkat kesukaan sosis ayam, sedangkan pada uji mutu hedonik menunjukkan hasil berpengaruh nyata $(\mathrm{P}<0,05)$ terhadap rasa sosis ayam. Kesukaan panelis terhadap rasa sosis dengan penambahan ekstrak daun sirsak 4\% menunjukkan nilai 3 (agak suka) sampai 4 (suka), sementara mutu hedonik rasa sosis dengan penambahan ekstrak daun sirsak 6\% menunjukan nilai 1 (tidak pahit) sampai 2 (sedikit pahit). Tanjung (2016) berpendapat bahwa rasa pahit yang ditimbulkan pada sosis yang telah diberi penambahan ekstrak daun sirsak dipengaruhi oleh tanin yang membawa rasa sepat dan pahit yang diperoleh dari daun sirsak. Lebih lanjut ditambahkan oleh Maharani et al. (2017) bahwa rasa pahit yang ditimbulkan tidak hanya pada senyawa tanin saja, tetapi timbul dari senyawa alkaloid yang terdapat pada daun sirsak. Semakin banyak daun sirsak yang diberikan akan menimbulkan rasa yang semakin pahit. Rasa merupakan faktor penting dalam produk pangan, sebab rasa merupakan faktor penentu penerimaan atau penolakan suatu produk oleh panelis. Panelis akan menolak suatu produk, jika rasa pada produk tersebut memiliki rasa yang tidak enak meskipun aroma, warna dan tekstur bahan pangan dinilai baik.

\section{UJI ANTIOKSIDAN SOSIS}

Pengujian antioksidan pada sosis dilakukan dengan menggunakan metode DPPH. Pengujian antioksidan dilakukan pada adonan sosis dan sosis masak dengan membandingkan hasil dari keduanya. Hasil pengujian antioksidan dapat dilihat pada Gambar 5. 
Hasil pengujian antioksidan adonan sosis dan sosis masak dengan penambahan ekstrak daun sirsak dengan level yang berbeda menunjukkan hasil yang berpengaruh nyata $(\mathrm{P}<0,05)$ terhadap antioksidan sosis ayam. Berdasarkan hasil uji antioksidan diketahui bahwa semakin tinggi dosis ekstrak daun sirsak yang diberikan pada sosis, maka semakin tinggi kandungan antioksidan yang didapat. Antioksidan tertinggi terdapat pada adonan sosis dengan penambahan ekstrak daun sirsak sebesar $6 \%$ dan antioksidan terendah terdapat pada sosis kontrol. Semakin banyak ekstrak daun sirsak yang diberikan maka semakin meningkat pula kandungan antioksidan yang diperoleh hal ini sesuai dengan pendapat Kurniasih (2015) yang menyatakan bahwa senyawa aktif flavanoid yang terdapat pada daun sirsak bermanfaat sebagai antioksidan. Pratiwi et al. (2017) menyatakan bahwa minyak atsiri yang terdapat pada daun sirsak mengandung senyawa terpenoid $(81,79 \%)$, alkaloid $(9,36 \%)$, dan fenolik $(8,85 \%)$ yang memiliki manfaat sebagai antioksidan. Penambahan bahan bawang putih dan ketumbar pada sosis ayam dapat meningkatkan kadar antioksidan. Hal ini sesuai dengan Prasonto et al. (2017) yang menyatakan bahwa bawang putih memiliki kandungan antioksidan dan Khumaini et al. (2012) yang menyatakan bahwa ketumbar memiliki kandungan antioksidan. Bumbu yang digunakan pada pembuatan sosis telah melalui proses pengolahan menjadi bentuk bubuk dan takaran setiap penambahan bumbu selalu ditimbang dengan berat yang sama untuk setiap perlakuan agar tidak mempengaruhi kadar antioksidan pada sosis yang diberi penambahan ekstrak daun sirsak.

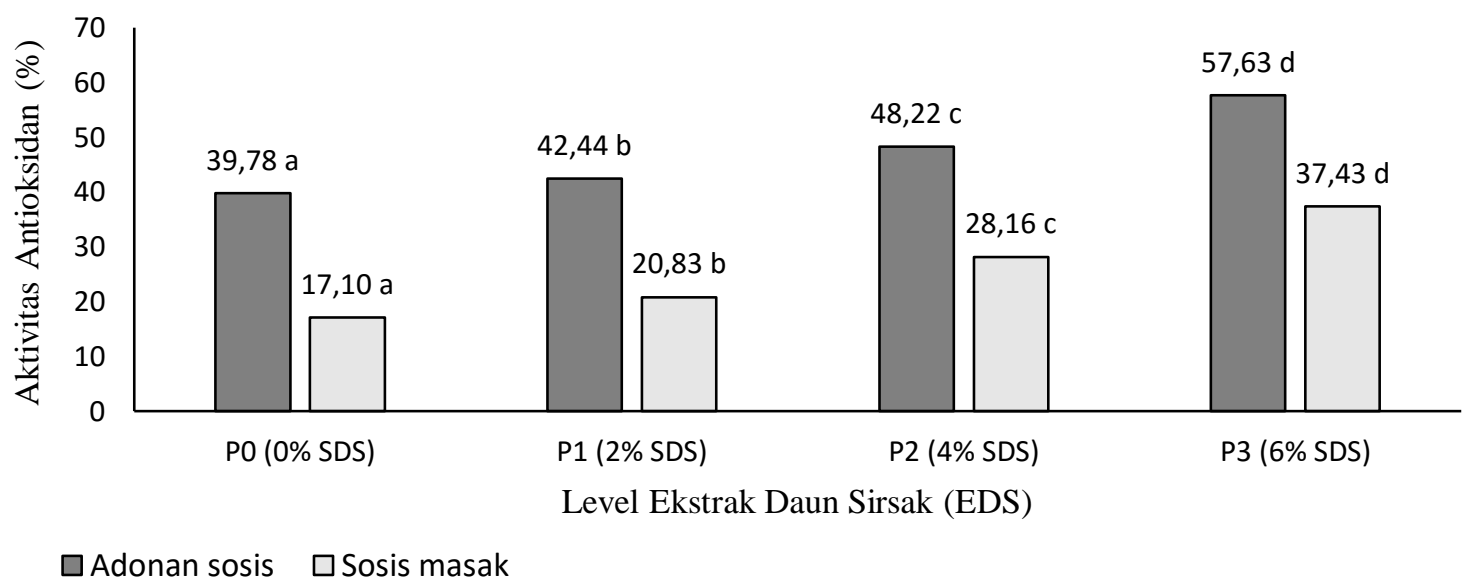

Gambar 5. Uji antioksidan sosis

Sosis yang telah dimasak mengalami penurunan antioksidan yang berpengaruh nyata $(\mathrm{P}<0,05)$ terhadap antioksidan sosis ayam. Antioksidan pada sosis yang telah dimasak mengalami penurunan dari adonan sosis yang belum dimasak. Penurunan antioksidan pada sosis yang telah dimasak disebabkan oleh suhu pada saat pengukusan sosis. Pendapat ini sesuai dengan Wicaksono dan Zubaidah (2015) yang menyatakan bahwa perebusan dapat menurunkan kadar antioksidan. Senyawasenyawa yang terdapat dalam daun sirsak pada suhu $60{ }^{\circ} \mathrm{C}$ dapat merubah struktur, sehingga dapat disimpulkan bahwa pemanasan yang berlebih pada saat pengolahan akan menyebabkan sel terdegradasi, sehingga antioksidan menjadi menurun.

\section{KESIMPULAN}

Penambahan ekstrak daun sirsak level 0\%, $2 \%, 4 \%$ dan $6 \%$ kedalam sosis ayam tidak berpengaruh pada sifat fisik dan tingkat kesukaan sosis ayam tetapi berpengaruh pada organoleptik dan aktivitas antioksidan. Ekstrak daun sirsak pada level 4\% yang ditambahkan pada sosis ayam memperlihatkan pengaruh yang paling optimum ditinjau dari parameter uji organoleptik dan antioksidan. 


\section{DAFTAR PUSTAKA}

Afrianti M, Dwiloka B dan Setiani BE. 2013. Perubahan Warna, Profil Protein dan Mutu Organoleptik Daging Broiler Setelah Direndam dengan Ekstrak Daun Senduduk. Jurnal Aplikasi Teknologi Pangan. Vol 2 (3).

Anggraeni DA, Widjanarko SB dan Ningtyas DW. 2014. Proporsi Tepung Porang (Amorphophallus muelleri Blume): Tepung Maizena Terhadap Karakteristik Sosis Ayam. Jurnal Pangan dan Agroindustri. Vol 2 (3).

Aulia, Z. 2017. Pengaruh Penambahan Puree Sirsak (Annona muricata L.) dan Ekstrak Daun Sirsak Terhadap Sifat Organoleptik Es Krim. E-journal Boga. Vol 5 (1).

Bouton PE, Harris PV, Macfarlane JJ dan O'Shea JM. 1978. Sifat Fisik dan Parameter Spesifik Kualitas Daging. Hal: 263-313. dalam Soeparno. Ilmu dan Teknologi Daging. Cetakan Pertama. Gadjah Mada University. Yogyakarta.

Chintya N dan Utami B. 2017. Ekstraksi Tannin dari Daun Sirsak (Annona muricata L.) sebagai Pewarna Alami Tekstil. Journal Cis-Trans (JC-T). Vol 1 (1).

Cresna, Napitupulu M dan Ratman. 2014. Analisis Vitamin C pada Buah Pepaya, Sirsak, Srikaya, dan Langsat yang Tumbuh di Kabupaten Donggala. Jurnal Akademika Kimia. Vol 3 (3).

Diantoro A, Rohman M, Budiarti R dan Palupi HT. 2015. Pengaruh Penambahan Ekstrak Daun Kelor (Moringa oleifera L.) Terhadap Kualitas Yoghurt. Jurnal Teknologi Pangan. Vol 6 (2).

Farhan H, Rammal H, Hijazi A, Hamad H, Daher A, Reda M dan Badran B. 2012. Invitro Antioxidant Activity of Ethanolic and Aqueous Extracts from Crude Malva parviflora L. Grown in Lebanon. Asian Journal of Pharmaceutical and Clinical Research. Vol 5 (3): 234-238.

Fauziah FF, Juswono UP, Herwiningsih S.2012. Pengaruh Pemberian Buah Manggis, Buah Sirsak dan Kunyit Terhadap Kandungan Radikal Bebas pada Daging Sapi yang Diradiasi dengan Sinar Gamma. [Disertasi]. Malang : Fakultas
Matematika dan Ilmu Pengetahuan Alam, Universitas Brawijaya.

Irawati A, Warnoto dan Kususiyah. 2015. Pengaruh Pemberian Jamur Tiram Putih (Pleurotus ostreatus) Terhadap pH, DMA, Susut Masak, dan Uji Organoleptik Sosis Daging Ayam Broiler. Jurnal Sain Peternakan Indonesia. Vol 10 (2).

Ismanto A, Julianda T, Mursidah. 2018. Analisis Sikap Dan Kepuasan Konsumen Terhadap Atribut Produk Karkas Ayam Pedaging Segar di Pasar Tradisional Kota Samarinda. Jurnal Ilmu Peternakan dan Veteriner Tropis Vol 8 (2): 69 - 82

Khotimah K dan Hartatie ES. 2013. Kualitas Fisika Kimia Sosis Ayam dengan Penggunaan Labu Merah (Curcubita moschata) sebagai Alternatif Pengganti Pewarna dan Antioksidan. Jurnal Ilmu Ternak. Vol 13 (1).

Kurniasih N, Kusmiyati M, Nurhasanah, Sari RP dan Wafdan R. 2015. Potensi Daun Sirsak (Annona muricata Linn.) Daun Binahong (Anredera cocdifolia (Ten) Steenis) dan daun benalu Mangga (Dendrophthoe pentandra) Sebagai Antioksidan Pencegah Kanker. Jurnal Kimia. Vol IX (1).

Laksmi RT, Legowo AM dan Kusrahayu. 2012. Daya Ikat Air, pH, dan Sifat Organoleptik Chicken Nugget yang Disubtitusi dengan Telur Rebus. Animal Agriculture Journal. Vol 1 (1).

Maharani S, Setyobroto I dan Susilo J. 2017. Kajian Variasi Pengolahan Teh Daun Sirsak, Sifat Fisik, Organoleptik dan Kadar Vitamin E. Jurnal Teknologi Kesehatan. Vol 13 (2).

Khumaini A, Mudawaroch RE, Hanung DA. 2012. Pengaruh penambahan sari kunyit (Curcuma domestica val) dalam air minum terhadap konsumsi pakan dan konsumsi air minum ayam broiler. Surya Agritama. 1(2):85-93.

Prasonto D, Riyanti E dan Gartika, M. 2017. Uji Aktivitas Antioksidan Ekstrak Bawang Putih (Allium sativum). ODONTO Dental Journal. Vol 4 (2).

Prastini AI dan Widjanarko SB. 2015. Pembuatan Sosis Ayam Menggunakan Gel Porang (Amorphophallus mueleri Blume) 
sebagai Bahan Pengikat Terhadap Karakteristik Sosis. Jurnal Pangan dan Agroindustri. Vol 3 (4).

Pratiwi YI, Purwanti S dan Damayanti DS. 2017. Pengaruh Pemberian Secara Subkronik Minyak Atsiri Daun Sirsak (Annona muricata Linn.) terhadap Kadar Low Density Lipoprotein (LDL) dan High Density Lipoprotein (HDL) Serum Tikus Wistar. Journal of Islamic Medicine Research. Vol 1 (1).

Rosida DF, Sarofa U dan Dewi RC. 2015. Karakteristik Fisiko Kimia Sosis Ayam dengan Penggunaan Konsentrat Protein Biji Lamtoro Gung (Leucaena leucocephala) sebagai Emulsifier. Jurnal Rekapangan. Vol 9 (1).

Sofiana A. 2012. Penambahan Tepung Protein Kedelai Sebagai Pengikat pada Sosis Sapi. Jurnal Ilmiah Ilmu-Ilmu Peternakan. Vol XV (1).

Suradi K. 2006. Perubahan Sifat Fisik Daging Ayam Broiler Post Mortem Selama
Penyimpanan Temperatur Ruang (Change of Physical Characteristics of Broiler Chicken Meat Post Mortem During Room Temperature Stroge). Jurnal Ilmu Ternak. Vol 6 (1): 23-27.

Tanjung R, Hamzah F, Efendi R. 2016. Lama Fermentasi Terhadap Mutu Teh Daun Sirsak (Annona muricata L.). JOM Faperta UR. Vol 3 (2).

Wicaksono GS dan Zubaidah E. 2015. Pengaruh Karagenan dan Lama Perebusan Daun Sirsak Terhadap Mutu dan Karakteristik Jelly Drink Daun Sirsak. Jurnal Pangan dan Agroindustri. Vol 3 (1). Yusuf M, Wihansah RRS, Arifin M, Oktaviana AY, Rifkhan, Negara JK dan Sio AK. 2016. Kualitas Fisik, Mikrobiologi dan Organoleptik Sosis Ayam Komersil yang Beredar di Tempat Berbeda di Bogor. Jurnal Ilmu Produksi dan Teknologi Hasil Peternakan. Vol 04 (2). 